\title{
ANALISIS KARAKTERISTIK PESERTA DIDIK
}

\author{
Ahmad Taufik
}

STAI Bumi Silampari Lubuklinggau ahmadtaufik201902@gmail.com

\begin{tabular}{ll}
\hline & Abstrak \\
\hline Article History & a teacher in conducting the learning \\
Received:01-02-2019 & planning process needs to understand the \\
Revised : 15-02-2019 & characteristics and initial abilities of \\
Accepted:20-02-2019 & students. Analysis of learners initial \\
Keywords : & abilities is an activity of identifying \\
Teacher interaction, & learners in terms of needs and \\
emotional, & characteristics to determine behavioral \\
teaching and learning & or goal and material specifications and \\
process. & qualifications.Interaction between \\
& teacher and students, students and others \\
& are no longer unilateral but are more \\
& emotional and sympathetic or interactive \\
& relationships through the teaching and \\
& learning process. Students are no longer \\
& an object of education but have been \\
& reduced to polarization of thinking by \\
& stating that students as students, a fun \\
& and exciting interaction process makes \\
& learning effective.
\end{tabular}

\section{Pendahuluan}

Berdasarkan hal tersebut, Sebelum menyusun dan mengembangkan silabus dan RPP, maka seyogyanya seorang guru telah memahami subjek atau peserta didiknya. Karena peserta didik memiliki beragam atau heterogen tingkat pengetahuan, sikap, dan ketrampilan yang dimiliki dari hasil pembelajaran pada jenjang pendidikan sebelumnya. Menurut Kasful Anwar interaksi antara peserta didik dan pendidik akan menghasilkan kematangan yang tampak dan perubahan tingkah laku yang dipengaruhi oleh ilmu 
pengetahuan yang diperolehnya dari proses belajar (Kasful Anwar, 2006: 50).

Sementara itu Samsudin menjelaskan secara rinci tentang perubahan dalam konteks belajar yang dilakukan peserta didik dapat bersifat fungsional atau struktural, material,behavioral, serta keseluruhan pribadi (Syamsudin Makmun, 2003: 159). Lebih lanjut ditegaskan Thorndike mengatakan bahwa belajar adalah proses orang memperoleh berbagai kecakapan, ketrampilan, dan sikap sebagai akibat dari sejumlah tindakan dan perilaku kompleks yang dialami oleh peserta didik dalam belajar (Kasful Anwar, 2006: 54). Oleh sebab itu, seorang guru dalam melakukan proses perencanaan pembelajaran perlu memahami tentang karakteristik dan kemampuan awal peserta didik. Analisis kemampuan awal peserta didik merupakan kegiatan mengidentifikasi peserta didik dari segi kebutuhan dan karakteristik untuk menetapkan spesifikasi dan kualifikasi perubahan perilaku atau tujuan dan materi.Maka dari itu penulis memilih judul artikel "analisis karakteristik peserta didik".

\section{Pembahasan}

\section{Pengertian Karakteristik Peserta Didik}

Seorang guru dalam proses perencanaan pembelajaran perlu memahami tentang karakteristik dan kemampuan awal peserta didik. Analisis kemampuan awal peserta didik merupakan kegiatan mengidentifikasi peserta didik dari segi kebutuhan dan karakteristik untuk menetapkan spesifikasi dan kualifikasi perubahan perilaku atau tujuan dan materi. Karakteristik peserta didik didefinisikan sebagai ciri dari kualitas perorangan peserta didik yang ada pada umumnya meliputi antara lain kemampuan akademik, usia dan tingkat kedewasaan, motivasi terhadap mata pelajaran, pengalaman, ketrampilan, psikomotorik, kemampuan kerjasama, serta kemampuan sosial (Atwi Suparman, 2001: 123).

Disamping pemahaman karakteristik umum diatas, terdapat juga karakteristik khusus yang disebut dengan non konvesional yang meliputi kelompok minoritas (suku), cacat, serta tingkat kedewasaan. Hal ini berpengaruh pada penggunaan bahasa, penghargaan atau pengakuan, perlakuan khusus, dan metode strategi dalam proses pengajaran. 


\section{Karakteristik peserta didik}

Ada dua karakteristik kemampuan awal peserta didik yang perlu dipahami oleh guru yakni:

1) Latarbelakang akademik

a. Jumlah peserta didik

Guru perlu mengetahui beberapa jumlah peserta didik yang akan diajar untuk mengetahui apakah mengajar pada kelas kecil atau kelas besar. Pemahaman guru terhadap jumlah peserta didik akan mempengaruhi persiapan guru dalam menentukan materi, metode, media, waktu yang dibutuhkan, dan evaluasi pembelajaran yang dilaksanakan. Untuk mengetahui jumlah peserta didik maka guru dapat berkoordinasi dengan bagian akademik.

b. Latar belakang peserta didik

Pemahaman guru terhadap latar belakang peserta didik seperti latar belakang keluarga, ekonomi, tingkat hobi dan lain sebagainya juga berpengaruh terhadap proses perumusan perencaan sistem pembelajaran. Untuk memperoleh data tentang latar belakang peserta didik dapat diperoleh melalui pengisian biodata oleh peserta didik.

c. Indeks prestasi

Indeks prestasi peserta didik juga menjadi penting untuk diketahui oleh guru, agar materi yangd diberikan sesuai dengan kemampuan:

- Dapat disesuaikan dengan tingkat prestasi yang mereka miliki.

- Bahkan peserta didik yang memiliki tingkat prestasi yang homogen dapat ditempatkan pada kelas yang sama.

- Guru juga bisa mempertimbangkan tingkat keluasaan dan kedalaman materi yang disampaikan dengan prestasi yang dimiliki peserta didik.

Untuk mengetahui indeks prestasi peserta didik dapat diperoleh melalui nilai raport sebelumnya atau seleksi kemampuan awal peserta didik yang diselenggarakan oleh lembaga.

d. Tingkat intelegensi

Memahami tingkat intelegensi peserta didik juga dapat mengukur dan memprediksi: 
- Tingkat kemampuan mereka dalam menerima materi pelajaran.

- Mengukur tingkat kedalaman dan keluasan materi.

- Bahkan dengan memahami tingkat intelegensi peserta didik guru dapat menyusun materi, metode, media, serta tingkat kesulitan evaluasi terhadap tingkat intelegensi peserta didik.

Tingkat intelegensi peserta didik dapat diperoleh melalui tes intelegensi peserta didik atau tes potensi akademik.

e. Keterampilan membaca

Salah satu kecakapan yang harus dimiliki oleh peserta didik dalam belajar adalah ketrampilan membaca. Ketrampilan membaca adalah menyangkut tentang kemampuan peserta didik dalam menyimpulkan secara tepat dan akurat tentang bahan bacaan yang mereka baca. Untuk mengetahui tingkat ketrampilan membaca peserta didik dapat dilakukan melalui tes membaca dan menyimpulkan bahan bacaan dalam rentang waktu yang telah ditentukan.

f. Nilai ujian

Nilai ujian Juga dapat dijadikan sebagai pedoman untuk memahami karakteristik awal peserta didik. Untuk memperoleh nilai ujian peserta didik perlu dilakukan kemampuan awal peserta didik terhadap mata pelajaran yang diampu oleh guru yang bersangkutan.

g. Kebiasaan belajar/gaya belajar

Aspek lain yang perlu diperhatikan oleh guru dalam proses pembelajaran adalah memahami gaya belajar peserta didik atau disebut juga dengan learning style. Gaya belajar mengacu pada cara belajar yang lebih disukai oleh peserta didik. Dalam proses pembelajaran, banyak para peserta didik yang mengikuti belajar pada mata pelajaran tertentu, diajar dengan menggunakan strategi yang sama, akantetapi mempunyai tingkat pemahaman yang berbeda-beda.

Perbedaan ini tidak hanya disebabkan oleh tingkat kecerdasan peserta didik yang berbeda-beda, akan tetapi ditentukan oleh cara belajar yang dimiliki oleh masing-masing peserta didik. Seorang peserta didik yang senang membaca, kurang terbiasa belajar dengan baik jika dia harus mendengarkan ceramah atau diskusi. Demikian juga, peserta 
didik yang senang bergerak atau melalui berdiskusi tidak akan belajar dengan baik jika dia harus mendengarkan ceramah dari para guru. Lebih lanjut, gaya belajar atau learning style sering diartikan sebagai karakteristik dan preferensi atau pilihan peserta didik mengenai cara mengumpulkan informasi, menafsirkan, mengorganisir, merespon, dan memikirkan informasi tersebut (Hisyam Zaini, 2002: 45). Keanekaragaman gaya belajar peserta didik perlu diketahui oleh para guru pada awal belajar. Sehingga guru memiliki dasar dalam menentukan pendekatan dan media pembelajaran sangat ditentukan oleh kesesuaian antara pendekatan pembelajaran berdasarkan tingkat perkembangan psikologis dengan gaya belajar yang disukai oleh para peserta didik. Adapun prinsip efektivitas pembelajaran adalah kesesuaian pendekatan mengajar seorang guru dengan gaya belajar peserta didik.

h. Minat belajar

Minat belajar juga dapat dijadikan sebagai tolak ukur dalam memahami karakteristik peserta didik. Hal ini dilakukan agar guru dapat memprediksi atau melihat tingkat antusias peserta didik terhadap pembelajaran yang disampaikan. Oleh sebab itu guru perlu melakukan wawancara atau pengisian angket, agar dapat merangkum seluruh penilaian yang mencerminkan tentang minat peserta didik terhadap mata pelajaran yang akan disampaikan.

i. Harapan atau keinginan peserta didik

Harapan atau keinginan peserta didik terhadap mata pelajaran yang akan diberikan juga bisa dijadikan sebagai patokan guru dalam memahami karakteristik peserta didik. Hal ini dapat dilakukan dengan meminta peserta didik untuk mengemukakan pendapatnya tentang harapan mereka terhadap mata pelajaran yang akan diberikan, suasana yang diinginkan, serta tujuan yang ingin diperoleh dari mata pelajaran yang disajikan.

j. Lapangan kerja yang diinginkan

Hal ini yang dapat dilakukan dengan pengisian angket. Sehingga berdasarkan informasi ini seorang guru dapat memberikan bimbingan dan motivasi terhadap peserta didik 
dalam upaya pencapaian cita-cita mereka inginkan (Kemp, 1998: 131).

\section{Faktor-faktor sosial}

a. Usia

Faktor usia dapat dijadikan patokan dalam memahami karakteristik peserta didik. Memahami usia peserta didik akan berpengaruh terhadap pemilihan pendekatan pembelajaran yang akan dilakukan. Pendekatan belajar yang digunakan terhadap usia kanak-kanak tertentu saja berbeda dengan pendekatan belajar yang digunakan terhadap anak remaja atau dewasa. Dalam praktik pendidikan dikenal dengan istilah paedagogi dan andragogi. Pedagogi berasal dari bahasa yunani "paid" artinya anak dan "agogos" artinya membimbing. Itulah sebabnya istilah pedagogi dapat diartikan sebagai ilmu dan seni mengajar anak-anak. Sedangkan andragogi berasal dari bahasa yunani yakni "andra" artinya orang dewasa dan "agogos" artinya memimpin. Definisi istilah andragogi kemudian dapat diartikan sebagai suatu seni dan ilmu untuk membantu orang dewasa belajar.

b. Kematangan (maturity)

Kematangan juga dapat diartikan sebagai patokan dalam memahami karakteristik peserta didik, dimana kematangan secara psikologis juga menjadi pertimbangan guru dalam menentukan berbagai macam pendekatan belajar yang sesuai dengan tingkat usia atau kesiapan peserta didik. Dalam ilmu psikologi pendidikan kematangan ini disebut juga dengan perkembangan. Perkembangan merupakan suatu perubahan yang bersifat kualitatif dari fungsi-fungsi tubuh manusia baik jasmani maupun rohani (Wasty Soemanto, 1983: 22). Dari perkembangan jasmani dan rohani manusia yang terjadi pada setiap fase kehidupan manusia, mengarah kepada terjadinya proses kematangan. Kematangan ini mencakup:

- Kematangan pre natal yakni anak yang berusia 2,5 - 9 tahun akan mengalami kematangan fungsi syaraf serta refleksi untuk menggerakkan tubuh bayi. 
- Perkembangan vital yakni lahir, menangis, dan tak berdaya tetapi setelah mengalami fase tersebut ketiga aspek diatas dapat berfungsi dan menjadi matang

- Kematangan ingatan yakni $2-3$ tahun fungsi ingatan anak mulai berkembang, sehingga telah mampu menerima kesan dan ingatan serta menuju kesempurnaannya pada usia berikutnya.

- Kematangan imajinasi yakni pada anak usia $3-4$ tahun anak sudah merasa bahwa dirinya merupakan kepentingan dari orang lain. Bahkan dia telah mulai menyadari bahwa ia dibatasi oleh orang lain. Pada usia berikutnya imajinasi tersebut akan berkembang menuju kematangannya.

- Kematangan pengamatan yakni pada usia $4-6$ tahun sudah berkembang fungsi pengamatan untuk mengenal lingkungan sekitar, sehingga pada tahun-tahun berikutnya fungsi-fungsi kematangan menjadi dominan.

- Kematangan intelektual yakni pada anak usia 6 atau 7 tahun anak sudah mulai berfikir secara logi, baik dan buruk. Dan pada tahun berikutnya perkembangan dan fungsi intelektual anak akan menuju kematangannya sering juga disebut proses pembelajaran yang diperoleh.

Dengan demikian, pemahaman guru terhadap fase-fase perkembangan atau kematangan psikologis peserta didik dapat membantu guru dalam menentukan pendekatan pembelajaran peserta didik yang relevan dengan usia kematangan psikologis peserta didik (Wasty Soemanto, 1983: 75).

c. Rentangan perhatian (attention span)

Rentang perhatian peserta didik adalah jumlah waktu normal peserta didik dapat berkonsentrasi dalam mendengarkan uraian pembelajaran. Berdasarkan hasil penelitian yang dilakukan oleh Polio tahun 1984 terhadap mahasiswa menunjukkan bahwa mereka dapat berkonsentrasi penuh sekitar $60 \%$ dari jumlah waktu yang ada (Hisyam Zaini, 2002: 116).

Dengan demikian dapat dipahami bahwa memahami rentang perhatian peserta didik dalam belajar akan menentukan kualitas informasi yang diperoleh peserta didik dalam proses belajar.

d. Bakat- bakat istimewa

Sebagaimana dipahami bahwa setiap peserta didik memiliki berbagai macam potensi yang berbeda satu sama lainnya. Untuk 
itu guru perlu memahami perbedaan bakat tersebut agar dapat dikembangkan secara optimal.

e. Hubungan dengan sesama peserta didik

Berdasarkan penelitian ilmiah yang dilakukan, bahwa interaksi antara guru dan peserta didik, peserta didik dengan yang lainnya tidak lagi menjadi hubungan secara sepihak tetapi lebih jauh merupakan hubungan emosional dan simpatik atau interaktif lewat proses belajar mengajar. Peserta didik tidak lagi menjadi objek didik tetapi telah tereduksi dengan polarisasi pemikiran hari dengan menyatakan bahwa peserta didik sebagai subjek didik, proses interaksi yang menyenangkan dan menggairahkan menjadikan belajar yang efektif (Bobbi Depoter, 2000: 19).

Dengan demikian memahami hubungan antar peserta didik bisa membantu para guru dalam mengembangkan pendekatanpendekatan belajar yang bertumpu kepada kerjasama peserta didik dalam proses belajar.

f. Keadaan sosial ekonomi

Pemahaman guru terhadap keadaan sosial ekonomi para peserta didik juga dapat membantu guru dalam menentukan pendekatan dan sumber belajar. Secara kasat mata, dapat diperhatikan bahwa sebagian besar peserta didik mengalami kendala dalam memenuhi kebutuhan sumber belajar, sebagai akibat dari rendahnya ekonomi dalam keluarga. Berkenaan dengan hal itu, dibutuhkan kreatifitas guru dalam membuat atau menentukan sumber belajar dan media yang terjangkau dan tersedia di lingkungan belajar para peserta didik.

Manfaat memahami karakteristik peserta didik

Memahami berbagai macam karakteristik awal para peserta didik diatas memiliki beberapa manfaat yakni:

a) Memperoleh gambaran yang lengkap dan terperinci tentang kemampuan awal para peserta didik, yang berfungsi sebagai pra syarat bagi bahan baru yang akan disampaikan. Diharapkan bahan baru itu tidak terlalu mudah atau tidak terlampau sulit bagi peserta didik untuk mempelajarinya. Yang lebih baik ialah bahan baru tersebut merupakan kelanjutan pra syarat yang telah dimiliki oleh peserta didik sebelumnya. Dengan demikian diharapkan dapat tercapai tingkat keberhasilan belajar secara optimal. 
b) Memperoleh gambaran tentang luas dan jenis pengalaman yang dimiliki oleh peserta didik. Dengan berdasarkan pengalaman tersebut, guru dapat memberikan bahan yang lebih nyekrup dan memberikan contoh serta ilustrasi yang tidak asing bagi peserta didik. Dengan demikian, peserta didik akan lebih mudah menerima dan menyerap bahanbahan yang baru disajikan oleh para guru.

c) Mengetahui latar belakang sosial kultural para peserta didik, termasuk latar belakang keluarga, seperti tingkat pendidikan orang tua, tingkat sosial ekonomi, dan dimensidimensi kehidupan lainnya yang melatar-belakangi perkembangan sosial emosional dan mental mereka. Dengan demikian para guru dapat memberikan bahan yang lebih sesuai dengan metode yang lebih efisien.

d) Mengetahui tingkat pertumbuhan dan perkembangan peserta didik, baik jasmaniah maupun rohaniah. Tingkat perkembangan tersebut besar pengaruhnya terhadap keberhasilan belajar dan cara belajar peserta didik. Dengan demikian guru dapat merancang suatu rencana pengajaran yang lebih sesuai bagi mereka atas kesiapan membaca dan menunjuk para perilaku yang harus diperoleh oleh peserta didik sebelum peserta didik mulai membaca. Kematangan menunjuk pada pertumbuhan biologis yang terjadi berkat pengaruh hereditas, misalnya pertumbuhan berat, tingkat badan, besarnya otot, suara, dan lain-lain.

e) Untuk menentukan kelas-kelas tingkah laku awal ada tiga jenis alat yang dapat digunakan, yaitu perangkat belajar, kemampuan belajar, dan gaya belajar, antara yang satu dengan yang lainnya berhubungan dengan konsep tingkah laku awal.

f) Mengetahui aspirasi dan kebutuhan para peserta didik. Dengan cara itu guru dapat merancang strategi yang lebih tepat untuk memenuhi kebutuhan dan aspirasi itu, baik secara individual maupun secara kelompok.

Langkah-langkah analisis kemampuan peserta didik

Ada tiga langkah yang perlu dilakukan dalam mengadakan analisis kemampuan awal peserta didik berupa:

a. Melakukan pengamatan atau observasi kepada peserta didik secara perorangan. Pengamatan ini bisa dilakukan 
dengan menggunakan tes kemampuan awal, atau angket dan wawancara. Tes (lisan atau tulis kolektif) kemampuan awal digunakan untuk mengetahui konsep-konsep, prosedur-prosedur atau prinsip-prinsip yang telah dikuasai oleh pembelajar yang terkait dengan konsep, prosedur, atau prinsip yang akan diajarkan. Wawancara atau angket dapat digunakan untuk menggali informasi mengenai kemampuan awal yang lain, seperti pengetahuan yang tidak terorganissasi, pengetahuan pengalaman analogi, dan strategi kognitif.

b. Tabulasi karakteristik perorangan peserta didik. Hasil pengemasan yang dilakukan pada langkah pertama ditabulasi untuk mendapatkan klasifikasi dan rinciannya. Hasil tabulasi akan digunakan untuk daftar klasifikasi karakteristik menonjol yang perlu diperhatikan dalam penetapan strategi pengelolaan.

c. Pembuatan daftar strategi karakteristik peserta didik. Daftar ini perlu dibuat sebagai dasar menentukan strategi pengelolaan pembelajaran. Satu hal yang perlu diperhatikan dalam pembuatan daftar ini adalah daftar harus selalu disesuaikan dengan kemajuan-kemajuan belajar yang dicapai pembelajar secara perorangan.

\section{Metodologi Penelitian}

Dalam penelitian ini penulis memilih penelitian kualitatif sebagai metode penelitian. Hal itu didasarkan kepada beberapa alasan, yaitu pertama, karena studi kualitatif bertujuan mempelajari secara tentatif tentang latar belakang masalah bersifat sementara dan akan berkembang setelah penulis berada di lapangan. (Sugiyono, 2007: 238). Hal ini sesuai dengan apa yang sedang penulis lakukan, yaitu mempelajari tentang Kedua, karena studi kualitatif merupakan asumsi tentang gejala dari suatu objek sifatnya tunggal dan parsial. (Tohirin,2013:20). Dengan demikian gejala tersebut merupakan metode penelitian yang relatif tepat bagi penulis dapat menentukan variabel- variabel yang akan diteliti. Gejala tersebut bersifat holistik (menyeluruh, tidak dapat dipisahkan) yaitu situasi sosial meliputi aspek: tempat/ place, pelaku/ actor, aktivitas/ activity, yang semuanya berinteraksi secara sinergis. Ketiga, karena studi kualitatif memusatkan perhatian pada dokumen berupa catatan peristiwa yang 
sudah berlalu berbentuk tulisan, gambar, atau karya-karya monumental dari seseorang (Sugiyono, 2007: 329).

\section{Hasil dan Pembahasan}

Guru dalam melakukan proses perencanaan pembelajaran perlu memahami tentang karakteristik dan kemampuan awal peserta didik. Pemahaman guru terhadap jumlah peserta didik akan mempengaruhi persiapan guru dalam menentukan materi, metode, media, waktu yang dibutuhkan, dan evaluasi pembelajaran yang dilaksanakan. Untuk mengetahui jumlah peserta didik maka guru dapat berkoordinasi dengan bagian akademik.

Pemahaman guru terhadap latar belakang peserta didik seperti latar belakang keluarga, ekonomi, tingkat hobi dan lain sebagainya juga berpengaruh terhadap proses perumusan perencaan sistem pembelajaran. Untuk memperoleh data tentang latar belakang peserta didik dapat diperoleh melalui pengisian biodata oleh peserta didik.Aspek lain yang perlu diperhatikan oleh guru dalam proses pembelajaran adalah memahami gaya belajar peserta didik atau disebut juga dengan learning style. Gaya belajar mengacu pada cara belajar yang lebih disukai oleh peserta didik. Dalam proses pembelajaran, banyak para peserta didik yang mengikuti belajar pada mata pelajaran tertentu, diajar dengan menggunakan strategi yang sama, akantetapi mempunyai tingkat pemahaman yang berbedabeda.

Lebih lanjut, gaya belajar atau learning style sering diartikan sebagai karakteristik dan preferensi atau pilihan peserta didik mengenai cara mengumpulkan informasi, menafsirkan, mengorganisir, merespon, dan memikirkan informasi tersebut. Keanekaragaman gaya belajar peserta didik perlu diketahui oleh para guru pada awal belajar. Sehingga guru memiliki dasar dalam menentukan pendekatan dan media pembelajaran sangat ditentukan oleh kesesuaian antara pendekatan pembelajaran berdasarkan tingkat perkembangan psikologis dengan gaya belajar yang disukai oleh para peserta didik.

\section{Simpulan}

Dari penjelasan diatas dapat disimpulkan bahwa memahami usia peserta didik akan berpengaruh terhadap pemilihan pendekatan pembelajaran yang akan dilakukan. Pendekatan belajar yang 
digunakan terhadap usia kanak-kanak tertentu saja berbeda dengan pendekatan belajar yang digunakan terhadap anak remaja atau dewasa.

Interaksi antara guru dan peserta didik, peserta didik dengan yang lainnya tidak lagi menjadi hubungan secara sepihak tetapi lebih jauh merupakan hubungan emosional dan simpatik atau interaktif lewat proses belajar mengajar. Peserta didik tidak lagi menjadi objek didik tetapi telah tereduksi dengan polarisasi pemikiran hari dengan menyatakan bahwa peserta didik sebagai subjek didik, proses interaksi yang menyenangkan dan menggairahkan menjadikan belajar yang efektif. Dengan demikian memahami hubungan antar peserta didik bisa membantu para guru dalam mengembangkan pendekatanpendekatan belajar yang bertumpu kepada kerjasama peserta didik dalam proses belajar. 


\section{DAFTAR PUSTAKA}

Anwar, Kasful. 2006. Media, Sumber Belajar dan Pusat Sumber Belajar. IAIN Jambi: Jambi.

Makmun, Syamsudin. 2003. Psikologi Kependidikan: Perangkat Sistem Pengajaran Modul. Remaja Rosdakarya :Bandung.

Suparman, Atwi. 2001. Mengajar di Perguruan Tinggi(Konsep Dasar Pengembangan Kurikulum. Departemen Pendidikan Nasional.

Zaini, Hisyam. dkk. 2002. Desain Pembelajaran Perguruan Tinggi. IAIN Sunan Kalijaga: Yogyakarta.

Kemp, 1998. Proses Perancangan Pengajaran. ITB :Bandung.

Soemanto, Wasty. 1983. Psikologi Pendidikan: Landasan Kerja Pemimpin Pendidikan. Rineka Cipta: Jakarta.

Hemarchi, Mike \& Bobbi Depoter. 2000. Quamtum Learning. Bandung: Kaifa. 